\title{
Mycobacteria and TB
}




\section{Issues in Infectious Diseases}

\section{Vol. 2}

Series Editors

Heinz Zeichhardt, Berlin

Brian W.J. Mahy, Atlanta, GA

KARGER $\quad \begin{aligned} & \text { Basel } \cdot \text { Freiburg } \cdot \text { Paris } \cdot \text { London } \cdot \text { New York } \cdot \\ & \text { New Delhi } \cdot \text { Bangkok } \cdot \text { Singapore } \cdot \text { Tokyo } \cdot \text { Sydney }\end{aligned}$ 


\section{Mycobacteria and TB}

Volume Editors

Stefan H.E. Kaufmann, Berlin

Helmut Hahn, Berlin

16 figures, 1 in color and 11 tables, 2003

\footnotetext{
KARGER Basel $\cdot$ Freiburg $\cdot$ Paris $\cdot$ London $\cdot$ New York 


\section{Issues in Infectious Diseases}

Library of Congress Cataloging-in-Publication Data

Mycobacteria and TB / volume editors, Stefan H.E. Kaufmann, Helmut Hahn.

p. ; cm. - (Issues in infectious diseases, ISSN 1660-1890; v.2)

Includes bibliographical references and indexes.

ISBN 3805574592 (hard cover : alk. paper)

1. Tuberculosis. I. Kaufmann, S.H.E. (Stefan H.E) II. Hahn, H. (Helmut), 1937- III. Series.

[DNLM: 1. Tuberculosis-drug therapy. 2. Bacterial Vaccines. 3. Mycobacterium tuberculosis.

4. Tuberculosis-microbiology. 5. Tuberculosis, Multidrug-Resistant. WF 360 M995 2003]

RC311.M987 2003

$616.9^{\prime} 95061-\mathrm{dc} 21$

2002030001

This publication was edited by Brian WJ Mahy in his private capacity. No official support or endorsement by CDC is intended or should be inferred.

Drug Dosage. The authors and the publisher have exerted every effort to ensure that drug selection and dosage set forth in this text are in accord with current recommendations and practice at the time of publication. However, in view of ongoing research, changes in government regulations, and the constant flow of information relating to drug therapy and drug reactions, the reader is urged to check the package insert for each drug for any change in indications and dosage and for added warnings and precautions. This is particularly important when the recommended agent is a new and/or infrequently employed drug.

All rights reserved. No part of this publication may be translated into other languages, reproduced or utilized in any form or by any means electronic or mechanical, including photocopying, recording, microcopying, or by any information storage and retrieval system, without permission in writing from the publisher.

(C) Copyright 2003 by S. Karger AG, P.O. Box, CH-4009 Basel (Switzerland)

www.karger.com

Printed in Switzerland on acid-free paper by Reinhardt Druck, Basel

ISSN 1660-1890

ISBN 3-8055-7459-2 
This volume appears at the time when the International Course

The Immune System in the Protection

and

Susceptibility to Tuberculosis

is being held at the Scuola Superiore d'Immunologia Ruggero Ceppellini in Napoli/Italy, marking its 10th year of activity.

Since most of the authors of this volume, including the editors, are involved in this course, we are proud to recognize the activities of the School and its never tiring director, Prof. Serafino Zappacosta.

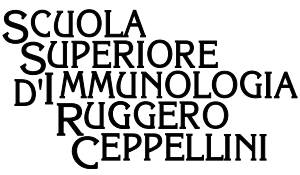




\section{Contents}

\section{Foreword}

IX Preface

1 Tuberculosis as a Global Public Health Problem Enarson, D.A. (Paris)

17 New Perspectives in the Molecular Epidemiology of Tuberculosis van Soolingen, D.; Kremer, K. (Bilthoven); Vynycky, E. (London)

46 Vaccination - The Current Status of BCG Clements, C.J. (Geneva)

67 Laboratory Diagnosis of Tuberculosis Pfyffer, G.E. (Zürich)

84 Mycobacteria and TB - Therapy and Drug Resistance Niemann, S.; Rüsch-Gerdes, S. (Borstel)

97 Molecular Biology of Mycobacterium tuberculosis Saunders, G.; McFadden, J. (Guildford)

112 Immunology and Persistence Ulrichs, T.; Kaufmann, S.H.E. (Berlin)

128 New Strategies for the Design of Vaccines against Tuberculosis Gicquel, B. (Paris)

137 Modern Drug Development Barry, C.E. III (Rockville, Md.)

151 Author Index

152 Subject Index 


\section{Foreword}

'Issues in Infectious Diseases', the new title of a series that started as 'Infectiology', aims to cover the most recent developments in infectious diseases from modern molecular biology, immunology, clinical sciences, vaccination, drug development, epidemiology to diagnostics. The two new series editors of 'Issues in Infectious Diseases' have set themselves the aim for the 'Issues' to cover the whole spectrum of infectious agents in state-of-the-art overviews of current interest.

The present issue focuses on mycobacteria and tuberculosis, and provides an impressive overview of the multiple facets of an infectious disease that remains one of the most serious and challenging infectious disease problems of the present day.

Heinz Zeichhardt, Free University of Berlin Brian W.J. Mahy, Centers for Disease Control, Atlanta 


\section{Preface}

One hundred and twenty years ago, on March 24, 1882, Robert Koch described his discovery of Mycobacterium tuberculosis that killed over $40 \%$ of the working class in Germany. Similar figures were recorded for all major cities in Europe and the USA. Of course, this is different nowadays, and many Western European countries consider tuberculosis a minor problem. However, the annual morbidity and mortality rates worldwide are in the order of 8 and 2 million cases, respectively, demonstrating that this disease is far from eradicated. In fact, the dangerous liaison between tuberculosis and HIV, the causative agent of AIDS, and the increasing incidences of multi-drug resistant (MDR) strains of M. tuberculosis in several parts of the world are worsening the problem. To date, 50 million people are already co-infected with HIV and M. tuberculosis, the risk of developing active disease in these individuals being dramatically higher. A similar number of people are infected with MDR strains of tuberculosis, and in certain countries over $10 \%$ of all tuberculosis cases are caused by MDR strains and therefore cannot be treated adequately.

Clearly, we do have drugs at hand to treat tuberculosis. However, the prolonged treatment time of up to 6 months with a combination of three different drugs renders chemotherapy unfeasible in developing countries and frequently results in the failure of patient compliance worldwide, which in turn fosters the development of MDR strains. Aside from the cost in lives, this causes the cost of treatment to increase by 100-fold, rendering the treatment of MDR strains in developing countries infeasible. As far as BCG vaccination is concerned, it protects against tuberculosis in newborns and young children only, but not 
against the most prevalent form of the disease, pulmonary tuberculosis in adults.

It is generally accepted that novel chemotherapeutic regimens as well as a novel vaccine are urgently required in order to control tuberculosis adequately, unless we accept a death toll of over 20 million in the first decade of this century.

Novel therapeutic and preventive measures will be best developed on the basis of our increasing knowledge about the molecular biology of the pathogen and the immunology of the host response. We now have a better understanding of the survival strategies of the pathogen as well as its unique Achilles' heel. Similarly, we are now beginning to understand how the immune response controls the pathogen quite efficiently but fails to eradicate it completely in the 2 billion people worldwide who are infected but do not develop the disease. It is the aim of this book to provide the reader with the latest scientific information about the two opponents in the trench warfare that takes place during M. tuberculosis infection.

We would like to cordially thank our colleagues who, by contributing to this volume, have generously shared their knowledge. We are also grateful to Lucia Lom-Terborg for her excellent help in editing this book.

Stefan H.E. Kaufmann

Helmut Hahn

Berlin 